\title{
THE MEDIATOR ROLE OF GLOBAL CONNECTEDNESS IN THE RELATIONSHIP BETWEEN LOGISTICS PERFORMANCE AND HUMAN DEVELOPMENT
}

Ümit ÇELEBं ${ }^{1}$

Mustafa Emre CIVELEK ${ }^{2}$
Received Date (Başvuru Tarihi): 30/10/2018

Accepted Date (Kabul Tarihi): 22/11/2018

Published Date (Yayın Tarihi): 04/01/2019

\begin{abstract}
Economic growth indicates a decent standard of living but it falls short of explaining human well-being and economic development in the long run. Human development, by being a broader concept, includes not only economic growth but also education and health indicators. It, therefore, better indicates longer term economic development and human well-being of a country. Number of studies already point to a significant relationship between logistics performance and economic growth. This research investigates whether a similar relationship between logistics performance and human development exists and the mediator role of global connectedness, which is related to both concepts. The purpose of this study, therefore, is to examine the mediator role of global connectedness in the relationship between logistics performance and human development. The results of the analysis show that global connectedness plays a partial mediator role in the relationship between logistics performance and human development.
\end{abstract}

Keywords: Logistics Performance Index, Global Connectedness Index, Human Development Index

JEL Codes: F15, F63, 131

\section{LOJISTIK PERFORMANS İLE İNSANI GELIŞMISSLIK ARASINDAKİ İLISSTIDE KÜRESEL BAĞLANTILILIĞIN ARA DEĞIŞKEN ROLÜ}

$\ddot{O} Z$

Ekonomik büyüme iyi bir yaşam standardı olduğunu göstermesine rağmen uzun vadede insani refahı ve ekonomik gelişmiş̧liği açıklamakta yetersiz kalmaktadır. İnsani geliş̧mişlik, daha geniş bir kavram olarak, sadece ekonomik büyümeyi değil, aynı zamanda eğitim ve sağllk göstergelerini de içermektedir. Dolayısıyla, bir ülkenin uzun vadeli ekonomik kalkınmasın ve insan refahın daha iyi gösterir. Lojistik performans ve ekonomik büyüme arasindaki anlaml ilişkiyi gösteren pek çok çalışma bulunmaktadır. Bu araştırma benzer ilişkinin lojistik performans ve insani gelişmişlik arasinda olup olmadığına bakmakta ve her iki kavramlada ilişkili olan küresel bağlanttllı̆ğın ara değişken rolünü incelemektedir. Analiz sonuçları küresel bağlantılllğ̆ın lojistik performans ve insani gelişmişlik arasındaki ilişkide kısmi ara değişken rolü bulunduğunu göstermektedir.

Anahtar Kelimeler: Lojistik Performans İndeksi, Küresel Bağlantılllık İndeksi, İnsani Gelişmişsik İndeksi

JEL Kodu: F15, F63, I31

\footnotetext{
${ }^{1}$ Dr. Öğr. Gör., İstanbul Ticaret Üniversitesi, umit.chelebi@ hotmail.com

${ }^{2}$ Dr. Öğr. Üyesi, İstanbul Ticaret Üniversitesi, ecivelek@ ticaret.edu.tr
}

http://orcid.org/0000-0002-2779-4168 http://orcid.org/0000-0002-2847-5126 


\section{INTRODUCTION}

The purpose of this study is to examine the mediator role of global connectedness in the relationship between logistics performance and human development. Human development aims at an inclusive growth and hence not only includes economic growth but it also incorporates other indicators that enhance well-being each and every human in the planet through the higher quality of education and health (UNDP, 2016; Dinda, 2014). Economic growth, being an important means to achieve human development - though by no means an end - has already been explained by number of variables in the literature and some of these leading variables are globalization, economic integration, foreign direct investment, technological advancement, competitiveness and logistics performance, to name but a few (Solow, 1956; Romer, 1990; Borensztein et.al., 1998; Dreher, 2006; Fagerberg and Srholec, 2005; Chu, 2012; Chien-Chiang Lee, 2015; Gries et. al., 2018; Munim and Schramm, 2018; Saidi and Hammami, 2014). Human development, on the other hand, being a broader concept than economic growth, looks at more than the material opulence of the economies (Mukherjee and Krieckhaus, 2011). Alongside the economic well-being, it aims to explain how profoundly rich human lives are and how better social opportunities are created as a result of higher economic growth (Sen, 1999). A higher income ensuring decent standards of living would undoubtedly be seen as an indispensable part of citizens' well-being, and yet it would only be meaningful if it ultimately brings with it a higher quality of life. Growing economically does not guarantee higher levels of human development and quality of life (Unnikrishnan and Jagannathan, 2015). In fact, it may even be a limited, if not a misleading indicator of well-being (Moshirian, 2008). Higher quality of life in essence necessitates people to have freedom to choose and fair access to education and health (UNDP, 2016; Sen, 2005). Alongside economic growth, the higher quality of life through freedom to choose and fair access to education and health in turn makes the economic development of the countries more durable. To look at mere increase of gross national income (GNI) per capita figure would not thus be sufficient to indicate a success of economic development in the long run. The increase of GNI per capita as an indicator of economic growth is considered to be the only one aspect of the process of economic development. The quality of life and human wellbeing through better education and health, alongside with economic growth, are recognized as other important aspects of economic development (Sen, 1999). As the importance of longer term sustainable development resonates among the larger public sphere, the attention of policy makers have since shifted towards enhancing human well-being as part of their overall 
objective of economic development (Mukherjee and Krieckhaus, 2011). This important shift of attention towards human development in turn necessitates as much economic as social and political factors to be taken into account (Kardam, 2005).

It is expected that logistics performance and global connectedness exert influence on human development in an increasingly globalizing world. Studies find logistics performance as being an important antecedent of economic growth, especially with its indirect role played via foreign direct investment and technological advancement (Chu, 2012; Munim and Schramm, 2018; Çelebi, 2018; Çelebi and Oktayer 2018; Çelebi et al., 2015). Foreign direct investment is seen as a primary indicator of global integration and connectedness (Dreher et. al., 2010). Technological advancement is one of the most critical parts of economic development explaining the differences in countries' development levels (Fagerberg et. al., 2009). As countries are getting more and more inter-connected globally through value chains, higher logistics performance becomes crucially important by ensuring a seamless flow of goods and services. These forces inevitably bring considerable impacts on human lives around the world. This study (by building on the earlier researches that determined the impact of logistics performance upon economic growth) aims to analyze the relations of logistics performance with human development via global connectedness, both of which, by being aggregate indicators, would enable the overall effect to be better seen, resulting therefore in further contributing to the field.

The initial driver triggering this study is to find out whether there is a relationship between logistics performance and human development. Global connectedness is related to both concepts. Therefore, the purpose of this study is to examine the mediator roles of connectedness in the relationship between logistics performance and human development.

In order to establish these inter-relations and determine the impact, the first part of this study will explain the definitions and background of the concepts in the model. The second part will consist of developing the hypotheses. The third part will outline the research method, sampling and measures. In the fourth part, the hypotheses will be tested and analyzed. The last part will draw the conclusion.

\section{BACKGROUND}

Logistics is conceptualized as the supply and delivery of the right product at the right place and at the right time, to the right user with the right and correct information by utilizing the most efficient and effective methods (Çelebi, 2018:19). The Logistics Management 
Council defines logistics as part of the supply chain process that plans, conducts and controls the efficient and effective flow and storage of goods, services and information from the production point to the consumption in order to meet customer needs (Long, 2003:5). As the world production and trade are increasingly taking place within global value chains (GVCs), the necessity of seamless supply of products and services from one country to another raise the importance of logistics performance (Memedovic et al., 2008:355).

Among various indicators (such as Liner Shipping Connectivity Index and Air Connectivity Index), International Logistics Performance Index (LPI) is recognized as one of the most comprehensive indicators measuring the performance of logistics processes (Ojala and Çelebi, 2016). The incorporation of the sub-indexes of both public and private features makes the LPI hold a holistic view of logistics performance. As such, while the customs and infrastructure sub-indexes stay mainly in the public realm, international shipments, timeliness, logistics competences, track and traces remain in essence within the private sphere. LPI has been published bi-annually by the World Bank since 2007 and its use and importance has been on the increase ever since (OECD/ITF, 2016).

There are various indexes developed to measure globalization. These are AT\&Kearney (AT Kearney/Foreign Policy, 2003), Dreher (2006) and Martens and Zywietz (2006) to name but a few. In addition to these indexes, DHL Global Connectedness Index (Ghemawat and Altman, 2016) is developed to reflect the depth and breadth of a country's integration with the rest of the world based on its flows of trade, capital, information and people. It is regarded as a proxy for globalization which is generally defined as a process of closer integration and global diffusion of goods, services, capital, information and people across national borders (Sirgy et. al., 2004). It is published on a yearly basis by Deutsche Post DHL Group.

The Human Development is on the other hand conceptualized as each and every human being living on the planet to enjoy the freedoms to fulfill one's full potential (UNDP, 2016). Human Development Index is based on education and health indicators as a minimal listing of capabilities alongside the economic well-being to capture basic quality of life (Sen, 2005). The rationale behind this is that higher income has no value if it is not translated into a higher life expectancy and better education to fulfill each and every individual's life aspirations (Mukherjee and Krieckhaus, 2011), an area that GNI or GDP indicators fail to capture (Sen, 2005). 


\section{HYPOTHESES DEVELOPMENT}

\subsection{The Effect of Logistics Performance Index on Global Connectedness Index}

Higher logistics performance, by enabling seamless flow of goods and services among nations, develops GVCs and facilitates global integration and connectedness. Alongside the advances made in communication and transport technology, the higher efficiency and effectiveness reached in logistics processes have been playing a critical impact on global connectedness (Levinson, 2006). Development of global air express industry, increased level of e-commerce logistics, digitalization of customs processes, development of modern means of transport, use of intermodal containers are few examples of elements that contributed to the logistics performance allowing higher speed and productivity and, in turn, positively affecting global connectivity (Ohmae, 1996; Togan, 2016).

In the light of the existing literature the following hypothesis is developed:

$\boldsymbol{H}_{1}$ : Logistics performance index has a positive effect on global connectedness index

\subsection{The Effect of Global Connectedness Index on Human Development Index}

Inter-relations and impacts of globalization on the economies attract number of critics as well as supporters. Thirlwall (2013) points to the widening gap of income inequality and rent especially in lower growth periods and that globalization and trade liberalization have not in fact alleviated. Stiglitz (2002) draws attention to the importance of social development policies to improve education, health and environment to counteract the free market policy failures of neo-liberal economics. Despite a number of critics on the benefits of globalization, there are many studies undertaken that have confirmed the positive impact of globalization on human development. Bergh and Nilsson (2010) find that economic globalization has a robust positive effect on life expectancy. Dreher et. al. (2012) find a positive effect of globalization and economic freedom on human rights especially on physical integrity rights. Dollar (2004) finds that global integration has been a positive force for improving peoples' lives around the world especially in the developing countries with a fast degree of globalization. Wolf (2004) finds a rise in life expectancy, standard of living and adult literacy in the developing world as results of economic liberalization and international integration. Krugman draws attention to the overall benefits of comparative advantage and its importance in retaining the openness of the economies towards each other. Bhagwati (2004) describes the globalization as a positive force of causing a virtuous cycle enabling a faster economic growth and development. Tsai (2007) finds that global flows and exchanges positively impact human well-being. 
In the light of the existing literature the following hypothesis is developed:

$\boldsymbol{H}_{2}$ : Global connectedness index has a positive effect on human development index

\subsection{The Effect of Logistics Performance Index on Human Development Index}

Easier, faster and cheaper access to products and services from around the world through higher level of logistics performance stimulates nations' level of human and economic development (OECD/ITF, 2015). The focus of logistics performance only upon trade and economic growth, does not make it a negligible driver of human development and well-being. As a matter of fact, the quality of physical infrastructure (especially in trade and transport) and in non-physical infrastructure (such as efficiency in administrative procedures) are two important pillars on which rests the economic development (Duranton et. al., 2014; Korinek and Sourdin, 2011). So much so that alongside trade and transport, physical infrastructure, development of institutional infrastructure and facilitation of trade to increase logistics performance exert an important influence on the sustainable economic development. As such, Sanchez et. al., (2014) finds that the rise in logistics performance positively impacts nations' economic development. Furthermore, timely delivery of goods and services through the quality and efficiency of international logistics services is critical. Especially the development of air express services as being the ready source of uplift around the world (not only of regular traffic but also of emergency deliveries) plays a crucial role in human and economic development (Morrell, 2011).

In the light of the existing literature the following hypothesis is developed:

H3: Logistics performance index has a positive effect on human development index

3.4. The Mediator Role of Global Connectedness Index in the Relationship between Logistics Performance Index and Human Development Index

Participation as well as investment in the GVCs requires countries to have wellfunctioning logistics process. Countries especially the developing ones - that are behind in their level of human development- with better logistics performance are able to lower trade costs and increase speed reaching consequently a higher level of global connectivity (Hoekman, 2014). Lower trade costs and a higher degree of global connectedness as a result of better logistics performance in turn enable the countries to improve their level of economic and human development. Alongside the improvement of physical as well as non-physical infrastructure, rapid advances of transport technology and logistics methods enable lower costs and higher speed, positively impacting globalization (Togan, 2016). In contrast, poor 
transport and trade infrastructures with higher costs and lower logistics performance cause a drop in global connectivity inhibiting economic development (Arvis et.al., 2015).

In the light of the existing literature the following hypothesis is developed:

H4: Global connectedness index has a mediator role on the relationship between logistics performance index and human development index

\section{RESEARCH METHOD}

Mediator analysis was conducted by using the method suggested by Baron and Kenny. According to Baron and Kenny, a variable plays a mediator role when the following conditions are met (Baron \& Kenny, 1986):

- Change in the independent variable causes the mediator variable to change,

- $\quad$ change in the mediator variable causes the dependent variable to change and

- When the mediator and the independent variables are included into the analysis together, the influence of the independent variable on the dependent variable decreases or completely disappears.



Figure 1. Conceptual Model

In Figure 1, the conceptual model of the research is shown. Hierarchical regression is used in order to test the hypotheses. Regression equations are as follows among constructs which are logistics performance index (LPI), global connectedness index (GCI) and human development index (HDI): 
Model 1: HDI $=\beta_{0}+\beta_{1} \cdot$ LPI $+\varepsilon\left(\mathrm{H}_{3}\right)$

Model 2: GCI $=\beta_{0}+\beta_{1} \cdot \mathrm{LPI}+\varepsilon\left(\mathrm{H}_{1}\right)$

Model 3: HDI $=\beta_{0}+\beta_{1} \cdot \mathrm{LPI}+\beta_{2} \cdot \mathrm{GCI}+\varepsilon\left(\mathrm{H}_{2}\right.$ and $\left.\mathrm{H}_{4}\right)$

\section{MEASURES AND SAMPLING}

LPI, GCI and HDI indexes were used. Due to the fact that secondary data were used there was no need to determine the validity and reliability of the scales. Therefore confirmatory factor analysis was not conducted.

Logistics Performance Index (LPI) is an indicator of logistics performance published by World Bank since 2007 consisting of six components: customs, infrastructure, timeliness, international transport, logistics competencies, track and trace. It scales the country's logistics profile from 1 (worst) to 5 (best). LPI is based on the survey participants consisting of logistics experts around the world that are requested to evaluate the 8 countries with the highest business flow with their home country (Arvis et al., 2016).

Life expectancy, mean years of schooling and gross national income (GNI) are the three basic dimensions of Human Development Index (HDI). While life expectancy indicates a longer and healthier life, mean and expected years of schooling indicates an ability to have access to knowledge, and GNI per capita mirrors adequate standards of living. The data set is compiled from a number of sources cited in the technical note of HDI (UNDP, 2016:2). Life Expectancy at birth from UNDESA, expected and mean years of schooling are from UNESCO, Barro and Lee, UNICEF and multiple indicator cluster surveys and ICF macro demographic and health surveys. GNI per capita is from IMF, UNSD and World Bank (UNDP, 2016).

DHL Global Connectedness Index consists of trade, capital, information and people components as the four main types of cross border flows and measures the depth and breadth of the flows in the components globally. Depth measures the flows taking place internationally rather than domestically. Breadth, on the other hand, measures how much of a given country's international flows match with the global distribution of the same flow in the opposite direction. In other words how widely those flows are distributed among different nations (Ghemawat and Altman, 2016). Data set and statistics used to calculate the scores of the index are compiled from various and diverse sources (Ghemawat and Altman, 2016:241248). 


\section{ANALYSIS RESULTS}

Baron and Kenny's method firstly require a relationship among the variables shown in the model (Civelek, 2018). Therefore Pearson correlation coefficients were calculated. As shown in the Table 1 the relationships among variables are statistically significant.

Table 1. Correlation Coefficients

\begin{tabular}{lccc} 
& LPI & GCI & HDI \\
\hline LPI & 1 & & \\
\hline GCI &, $837^{*}$ & 1 & \\
\hline HDI &, $759 *$ &, $798^{*}$ & 1 \\
\hline \multicolumn{4}{l}{$*$} \\
\hline
\end{tabular}

Three models were developed to test the mediator effect. $\mathrm{R}$ and $\mathrm{R}^{2}$ values of these models are shown in Table 2.

Table 2. Model Summaries

\begin{tabular}{ccccc}
\hline Models & $\mathbf{R}$ & $\mathbf{R}^{\mathbf{2}}$ & Adjusted $\mathbf{R}^{\mathbf{2}}$ & $\begin{array}{c}\text { Standard } \\
\text { Error of the } \\
\text { Estimate }\end{array}$ \\
\hline Model 1 & 0,759 & 0,576 & 0,575 & 0,65180317 \\
\hline Model 2 & 0,837 & 0,700 & 0,700 & 0,54817113 \\
\hline Model 3 & 0,815 & 0,664 & 0,663 & 0,58083804 \\
\hline
\end{tabular}

Table 3. ANOVA Tables

\begin{tabular}{|c|c|c|c|c|c|c|}
\hline & Models & $\begin{array}{l}\text { Sum of } \\
\text { Squares }\end{array}$ & Df & $\begin{array}{c}\text { Mean } \\
\text { Square }\end{array}$ & $\mathbf{F}$ & Sig. \\
\hline \multirow{3}{*}{1} & Regression & 218,408 & 1 & 218,408 & 514,085 & ,000 \\
\hline & Residual & 160,592 & 378 & ,425 & & \\
\hline & Total & 379,000 & 379 & & & \\
\hline \multirow{3}{*}{2} & Regression & 265,414 & 1 & 265,414 & 883,267 & ,000 \\
\hline & Residual & 113,586 & 378 & 0,300 & & \\
\hline & Total & 379,000 & 379 & & & \\
\hline \multirow{3}{*}{3} & Regression & 251,810 & 2 & 125,905 & 373,193 &, 000 \\
\hline & Residual & 127,190 & 377 & 0,337 & & \\
\hline & Total & 379,000 & 379 & & & \\
\hline
\end{tabular}

In Table 3, ANOVA test results of each model are shown. ANOVA results show that the models are statistically significant. 
Table 4. Hypotheses Results

\begin{tabular}{lccc}
\hline \multicolumn{1}{c}{ Relationship } & Model 1 & Model 2 & Model 3 \\
\hline LPI $\rightarrow$ HDI & $0.759^{*}$ & & $0.305^{*}$ \\
LPI $\rightarrow$ GCI & & $0.837^{*}$ & $0.542^{*}$ \\
GCI $\rightarrow$ HDI & & &
\end{tabular}

Sobel test was conducted (Sobel, 1982) in order to verify the results reached by Baron and Kenny method. As shown in Table 5, Sobel test result is significant.

Tablo 5. Sobel Test Results

\begin{tabular}{lll}
\hline & Sobel Test Statistic & P \\
\hline LPI $\rightarrow$ GCI $\rightarrow$ HDI & 9.51499949 & 0,00 \\
\hline
\end{tabular}

\section{CONCLUSION}

As shown in Table 4, the results indicate significant and positive relation between LPI and GCI $\left(\beta_{\text {model2 }}=0.837, \mathrm{p}<0.01\right)$. Therefore $\mathrm{H}_{1}$ (logistics performance index has positive effect on global connectedness index) was supported. $\mathrm{H}_{2}$ (global connectedness index has positive effect on human development index) was also supported due to the fact that the relationship between HDI and GCI is statistically significant $\left(\beta_{\text {model } 3}=0.542, p<0.01\right) . \mathrm{H}_{3}$ (logistics performance index has positive effect on human development index) was supported ( $\left.\beta_{\text {model } 1}=0.759, \mathrm{p}<0.01\right)$ and $\mathrm{H}_{4}$ (global connectedness has a mediator role in the relationship between logistics performance and human development index) was partially supported $\left(\beta_{\text {model } 3}=0.305, \mathrm{p}<0.01\right)$. The reason is that after the inclusion of the mediator variable into the model the effect of LPI on HDI did not disappear. But the value of the $\beta$ coefficient seriously decreases. It was therefore concluded that GCI partially mediates in the relationship between LPI and HDI.

Motivation behind this research was to find out whether there is a relationship between logistics performance and human development and the results of this research have supported this relationship accordingly. The results also show that the global connectedness index plays a role in this relationship and this role has a partial mediator nature. These results lead to the following policy implications:

The efforts to improve the logistics performance of a country play a crucial role in the development of well-being of humans. In addition, policies increasing the global connectedness of a country should concurrently be implemented. 


\section{REFERENCES}

Arvis, J-F., Saslavsky, D., Ojala, L., Shepherd, B., Busch., C, Raj, A., Naula, T.,(2016),Connecting to Compete 2016, Trade Logistics in the Global Economy, LPI and Its Indicators, Washington,World Bank,pp. 1-62.

Arvis, J-F., Duval, Y., Shepherd, B., Utoktham, C., Raj, A., (2015), Trade Costs in the Developing World: 1995-2012, Developing Trade Consultants, Working Paper, 2, 1-41.

A.T. Kearney/Foreign Policy, (2003), Measuring Globalization, Foreign Policy Magazine Globalization Index, Jan-Feb 2003, 60-72.

Baron, R., \& Kenny, D., (1986), The Moderator - Mediator Variable distinction in Social Phychological Research: Conceptual, strategic and statistical Consideration. The Moderator - Mediator Variable distinction in Social Psychological Research Journal of Personality and Social Phychology, 1173-1182.

Bergh, A., Nilsson, T., (2010), Good for Living? On the relationship between Globalization and Life Expectancy, World Development, $8(1), 1191-1203$.

Bhagwati, J., (2004), In Defense of Globalization, Oxford, Oxford University Press.

Borensztein, E., De Gregorio, J., Lee, J-W., (1998), How does foreign direct investment affect economic growth?, Journal of International Economics, 45, 115-135.

Çelebi, Ü., (2018), Lojistiğin Ekonomideki Rolü, İstanbul, 1 ed., Ati Yayınları.

Çelebi, Ü., Civelek, M., Çemberci, M., (2015), The Mediator Effect of Foreign Direct Invesments on the Relation between Logistics Peformance and Economic Growth, Journal of Global Strategic Management, 9(1), 17-21.

Çelebi, Ü., Işıklar O., N., (2018), The Impacts of Logistics Performance upon Economic Growth through Foreign Direct Investment, Technological Development and Competitiveness: An Application of Structural Equation Modeling. Working article to be published.

Chu, Z., (2012), Logistics and economic growth: a panel data approach, Springer, Ann Reg Sci, 49, 87-102.

Civelek, M., (2018), Yapısal Eşitlik Modellemesi Metodolojisi, İstanbul, Beta.

Dinda, S., (2014), Inclusive growth through creation of human and social capital, International Journal of Social Economics, 41 (10), 878-895.

Dollar, D.,(2004), Globalization, Poverty, and Inequality since 1980, World Bank Policy Research Working Paper 3333, 1-46.

Dreher, A.,(2006), Does globalization affect growth? Evidence from a new index of globalization, Applied Economics, 38, 1091-1110.

Dreher, A., Gaston, N., Martens, P., Van Boxem, L., (2010), Measuring Globalization - Opening the Black Box. A Critical Analysis of Globalization Indices, Journal of Globalization Studies, 1(1), 166-185.

Dreher, A., Gassebner, M., Siemers, L-H.R.,(2012), Globalization, Economic Freedom and Human Rights, Journal of Conflict Resolution, 56(3), 516-546.

Duranton, G., Morrow M. P., Turner, A. M., (2014), Roads and Trade: Evidence from the US, Review of Economic Studies, 81, 681724.

Fagerberg, J., Srholec M., ( 2005), Catching Up: What are the Critical Factors for Success?”, UNIDO World Industrial Development Report,1-88.

Fagerberg, J., Mowery, C, D., Verspagen, B.,(2009), Innovation, Path Dependency and Policy, The Norwegian Case, Oxford University Press.

Ghemawat, P., Altman, S. A., (2016), DHL Global Connectedness Index, Deutsche Post DHL Group, Headquarters, Bonn, 1-248.

Gries, T., Grundmann, R., Palnau, I., Redlin, M., (2018), Technology diffusion, international integration and participation in developing economies - a review of major concepts and findings, Int Econ Policy, 15, 215-253.

Hoekman, B., (2014), Governance of Deeper Economic Integration in a Supply Chain World, Robert Schuman Centre for Advanced Studies, Florence, European University Institute.

Kardam, N., (2005), Turkey's Engagement with Global Women's Human Rights, Hants, Ashgate.

Korinek, J., Sourdin, P.,:(2011), To What Extent Are High-Quality Logistics Services Trade Facilitating”, OECD Trade Policy Papers, $108,1-41$

Lee, Chiang-Chien, Chi-Chuan Lee, Chun-Ping Chang, (2015), Globalization, Economic Growth and Institutional Development in China, Global Economic Review, 44 (1), 31-63.

Levinson, Marc: (2006), The Box, How the Shipping Container Made the World Smaller and the World Economy Bigger, Princeton New Jersey, Princeton University Press.

Long, D., (2003), International Logistics Global Supply Chain Management, Massachusetts, Kluwer Academic Publishers. 
Martens, P., Zywietz, D., (2006), Rethinking Globalization: A Modified Globalization Index, Journal of International Development 18, 331-350.

Memedovic, O., Ojala, L., Rodrigue, J-P., Naula, T., (2008), Fuelling the global value chains:what role for logistics capabilities?, Int. J. Technological Learning, Innovation and Development, Volume 1, Issue 3, pp. 353-374.

Morrell, S. P., (2011), Moving Boxes by Air, The Economics of International Air Cargo, Ashgate Publishing.

Moshirian, F., (2008), Globalisation, growth and insitutions, Journal of Banking \& Finance, 32, 472-479.

Mukherjee, N., Krieckhaus, J., (2011), Globalization and human well-being, International Political Science Review, 33(2), $150-170$.

Munim, H., Z., Schramm, H., J., (2018), The impacts of port infrastructure and logistics performance on economic growth: the mediating role of seaborne trade, Journal of Shipping and Trade, 3(1), 1-19.

OECD/ITF,(2015), Drivers of Logistics Performance A Case Study of Turkey, Corporate Partnership Board Report, 1-54.

OECD/ITF,(2016), Logistics Development Strategies and Performance Measurement, Roundtable Report, Paris, International Transport Forum, Issue 158, pp. 1-143.

Ohmae, K.,(1996), The End of The Nation State, London, Harper Collins Publishers.

Ojala, L., Çelebi, D., (2016), The World Banks's logistics performance index, LPI and drivers of logistics performance, Logistics Development Strategies and Performance Measurement, Paris, OECD/ITF, Issue 158, pp. 69-95.

Romer, P. M.,(1990), Endogenous Technological Change, Journal of Political Economy, 98 (5), 71-102.

Saidi, S., Hammami, S.,(2014), The Interaction Between Transportation, Foreign Direct Investment and Human Capital: A New Determinant of Economic Growth in Developing Countries (The Case of Tunisia), International Journal of Economics, Commerce and Management, 2(11), 1-22.

Sanchez, J. R.,Tomassian, C, G., Perrotti, E, D.,(2014), Economic Development and Logistics Performance, Revista de Economia Mundial, 38, 27-48.

Sen, A., (1999), Development as Freedom, New York, Alfred A.Knopf Inc.

Sen, A., (2000), Economics and Health, The Lancet, 354, siv20.

Sen, A., (2005), Human Rights and Capabilities, Journal of Human Development, 6 (2), 151-166.

Sirgy, M. J., Lee, D, Miller, C., Littlefield, E., J., (2004), The Impact of Globalization on a Country's Quality of Life: Toward an Integrated Model, Social Indicators Research, 68, 251-298.

Sobel, M., (1982), Asymptotic intervals for indirect effects in structural equations models. Sociological methodology, 290-312.

Solow, R.,(1956), A contribution to the theory of Economic Growth, Quarterly Journal of Economics, 70, (1), 65-94.

Stiglitz, Joseph E.,(2002), Participation and Development: Perspectives from the Comprehensive Development Paradigm, Review of Development Economics, 6 (2), 163-182.

Thirlwall, P, A.,(2013), Economic Growth in an Open Developing Economy, Cheltenham, Edward Elgar Publishing.

Togan, S., (2016), The Liberalization of Transportation Services in the EU and Turkey, Oxford, Oxford University Press.

Tsai, M-C., (2007), Does Globalization Affect Human Well-Being?, Social Indicators Research, 81, 103-126.

UNDP, (2016), Human Development Report, Human Development for Everyone, New York.

Unnikrishnan, R., Jagannathan, L.,(2015), A Study on Mediation Effect of Social Inclusion on Global Human Development, BVIMR Management Edge, 8 (1), 42-56.

Wolf, M., (2004), Why Globalization Works, New Haven, Yale University Press. 